\title{
STUDIES OF SODIUM AND POTASSIUM METABOLISM. THE EF- FECT OF POTASSIUM ON THE SODIUM AND WATER BALANCES IN NORMAL SUBJECTS AND PA- TIENTS WITH BRIGHT'S DISEASE
}

\author{
By EATON M. MACKAY ANd ALLAN M. BUTLER
}

(From the Hospital of the Rockefeller. Institute for Medical Research, New York)

(Received for publication July 22, 1935)

The work presented here was undertaken primarily for the purpose of ascertaining the effect of the ingestion of moderate amounts of potassium on the sodium balance of normal individuals and patients with Bright's disease. It was felt that such information would be of particular significance in appraising the efficiency of potassium salts as diuretics in the treatment of nephritic edema. Potassium chloride was selected as the means of administering the potassium in order to avoid the alkaline or cathartic effects of other potassium salts.

Incidentally, the experiments in supplying complete data on sodium and potassium balances and weight changes provide an opportunity for correlating sodium and potassium balances with the water balance of the body.

\section{LITERATURE}

In 1873 Bunge (1) in well controlled experiments showed that the ingestion of 387 milliequivalents of potassium as phosphate, citrate, or chloride (which as $\mathrm{KCl}$ is 28.2 grams) during a single day resulted in an increase in urinary sodium and chloride. From this he concluded that the ingestion of potassium salts caused withdrawal of sodium and chloride from the body. He left unanswered the question whether the continued intake of potassium would cause a continued withdrawal, especially under the condition of low sodium intake. In 1896 Pugliese (2) attempted to answer this very question by experiments on dogs. Some experiments showed an augmentation of sodium excretion after the ingestion of a potassium salt, while others failed to do so. Though his results were inconclusive he felt that potassium chloride acted as a diuretic. In 1911 Hart, McCollum, Steenbock and Humphrey (3) concluded that the amounts of potassium in the feed of herbivora did not affect their retention of sodium and chloride or influence their sodium chloride consumption.

Subsequent work has added to this conflicting evidence. Meyer and Cohn (4), Gerard $(5,6,7)$, and Wiley, Wiley and Waller (8) found that potassium administration to normal human subjects or animals caused a negative sodium balance. Miller's (9) experiments provided conflicting evidence. Loeb et al. (10) observed that potas- sium chloride administration in a normal subject caused a slight increase in total base excretion, probably due to increased urinary sodium, but no definite diuretic effect. They felt the observed changes in excretion were the result of changes in the urinary $\mathrm{pH}$ which resulted from the difference in the rate of excretion of potassium and chloride, and that the observed changes were not produced by a specific potassium ion effect. On the other hand, Richards, Godden and Husband (11) and Bassett, Elden and McCann (12) found that the addition of potassium citrate to the diet of a normal subject did not cause a negative sodium balance but did have a diuretic action.

In experiments on a nephritic patient Loeb et al. (10) obtained results similar to those observed in their normal subject. However, Bassett, Elden and McCann (12) found in contradistinction to their results on a normal subject that large doses of potassium citrate to a nephritic patient caused a diuresis and negative sodium and chloride balances.

Many qualitative studies have been reported on the differential effect of sodium and potassium ingestion on water balance. Blum $(13,14)$ in 1909 and 1920, in studying the edemas of diabetics, observed that the giving of $\mathrm{NaHCO}_{3}$ caused increase in weight, suppression of urine, and diminished chloride excretion, while the giving of $\mathrm{KHCO}_{3}$ had exactly the opposite effect. Meyer and Cohn (4) showed the same striking contrasts in infants following sodium and potassium ingestion where there was no limitation to the fluid intake. Schloss (15), Veil (16), Labbe and Voille (17), and Kempmann and Menschel (18) have reported similar findings.

The work of Gamble, Ross, and Tisdall (19) demonstrated the approximate constancy of the osmotic concentrations of the body fluids, and established a relationship between base and water balances. This led them to differentiate between the loss of extracellular water and intracellular water by the sodium, potassium and nitrogen content of the urine. Peters and Van Slyke (20) have summarized the findings of Gamble and coworkers by the following two formulae:

$$
\begin{aligned}
& \frac{\mathrm{Na}-0.425 \mathrm{~K}}{148}=\text { liters of extracellular water lost, } \\
& \frac{\mathrm{K}-0.017 \mathrm{Na}}{112}=\text { liters of cellular water lost, }
\end{aligned}
$$

where $\mathrm{Na}$ and $\mathrm{K}$ represent milliequivalents excreted in excess of intake. Blumgart and his collaborators (21), 


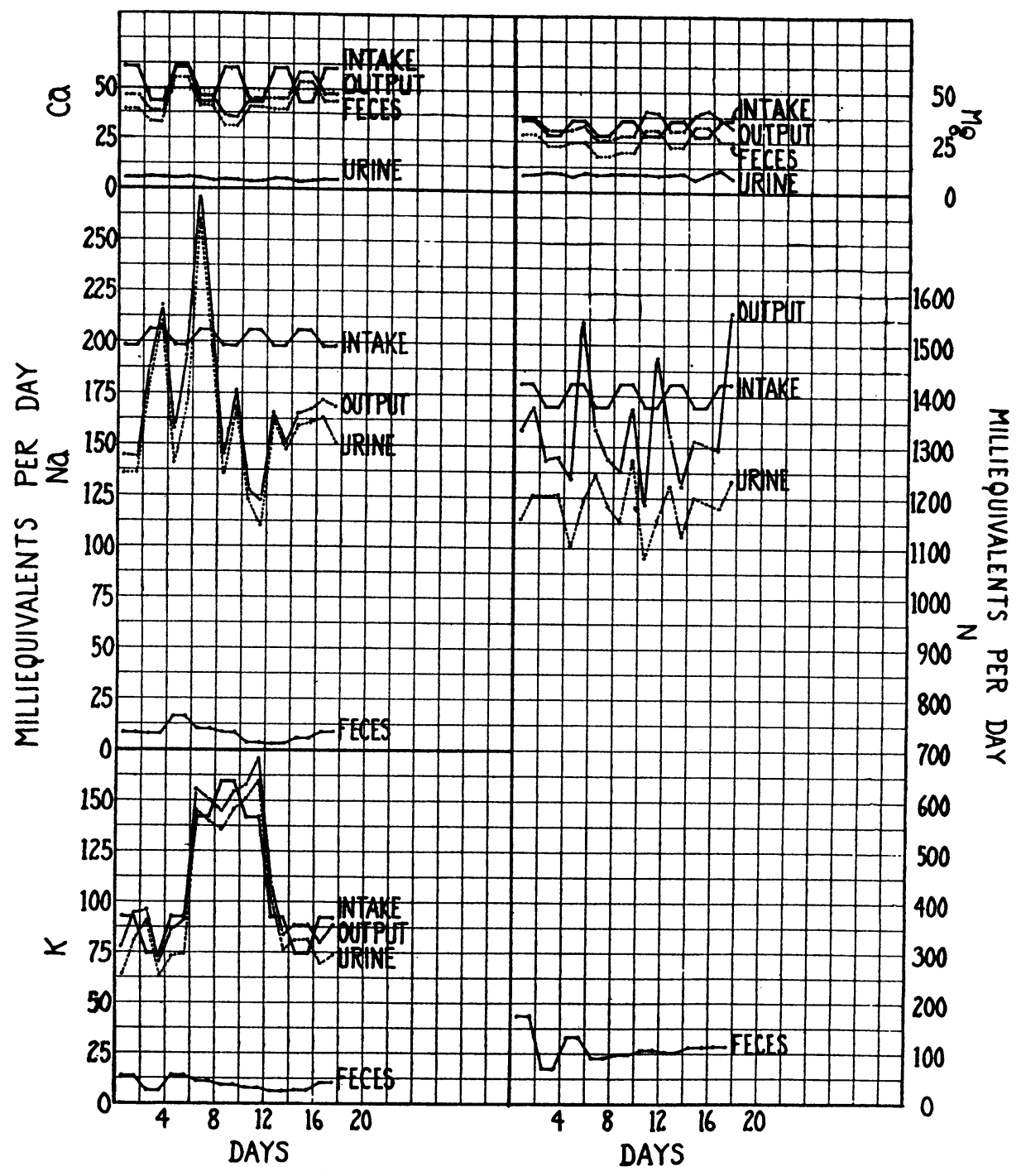

Fig. 1. Daily Balances, Experiment I, Normal Subject "B"

using this method of differentiating extracellular from intracellular water, have shown that approximately ninety per cent of the fluid lost from the body following the administration of mercurial and xanthine diuretics represents a loss of extracellular body fluids.

Recently Lavietes, D'Esopo and Harrison (22) have called attention to the discrepancies caused by fluctuations in the base concentration of body fluids in water balance calculated from base balances. They also showed that over short intervals of time estimated water balances from sodium or chloride balances agreed closely with the actual changes in weight in normal and nephritic subjects. Their data thus indicate that such weight changes over short intervals of time represent loss or retention of extracellular fluid and confirm the findings of the investigators already mentioned $(10,12,21)$.

Though the more recent papers referred to above $(10$,
$11,12,21,22)$ have appeared since our experiments were completed, our results are reported briefly because the slightly different experimental conditions provide additional information in a field of investigation where quantitative data are accumulated only at the expense of much time and labor.

\section{OUPLINE OF EXPERIMENT}

Two healthy young adult males, Subjects $M$ and $B$, served as normal subjects. Both were up and about carrying on their usual ward and laboratory routine during the course of the experiment. ${ }^{1}$ Each subject was

1 Subject "B" contracted a severe cold on the thirteenth day of Experiment I. The last six days of this experiment, therefore, cannot be considered as on a normal subject. 


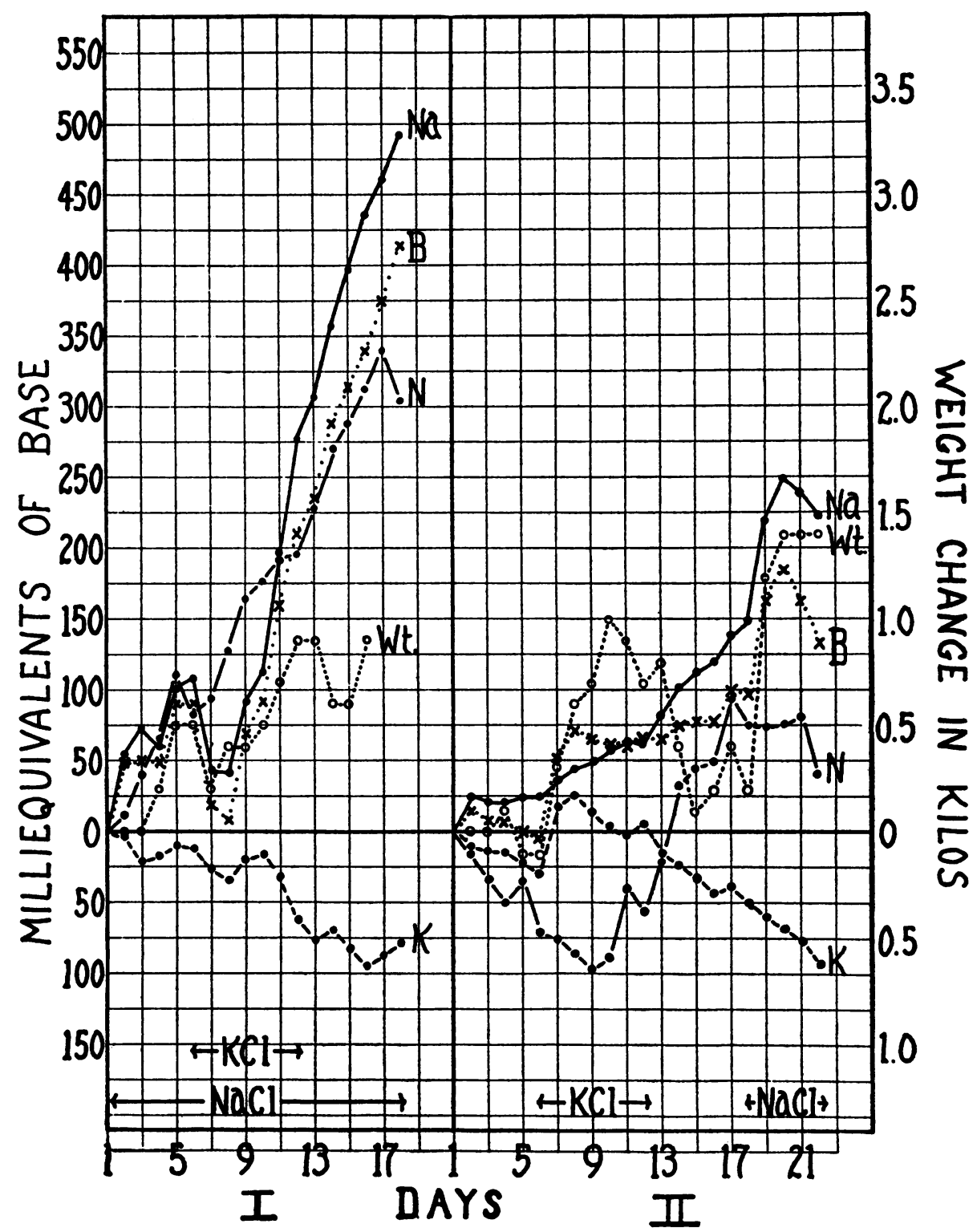

Fig. 2. Daily Cumulative Retentions, Experiments I and II with Normal Subjects M.eq. of base $\times 4=$ m.eq. of nitrogen.

given a constant weighed and analyzed diet for a foreperiod of six days and throughout the experiment. The diet consisted in each case of two different daily diets which were alternated during the experimental period. Each diet was given for two consecutive days followed by the other diet for the next two days and so on, alternating every two days. 2 The meals were prepared and served with as great accuracy as is possible in handling foodstuffs. Water was allowed as desired, the volume taken being recorded. At three different times during the

2 In Experiment III the two different daily diets were given on alternate days. experiments a duplicate of each of the diets was prepared. The three meals for the day reached the laboratory on dishes similar to those used for serving, and the food was removed from them with the same implements. Three duplicates of each diet were analyzed and gave the mineral intake data for the experiments. Our method of preparing the diets for analysis has been described (23).

The twenty-four hour urine specimens were collected without any preservative, the specimens being kept in an ice-box until the end of the period. The $\mathrm{pH}$, ammonia, and titratable acidity were determined daily.

Stool specimens were collected over 48 -hour periods. 


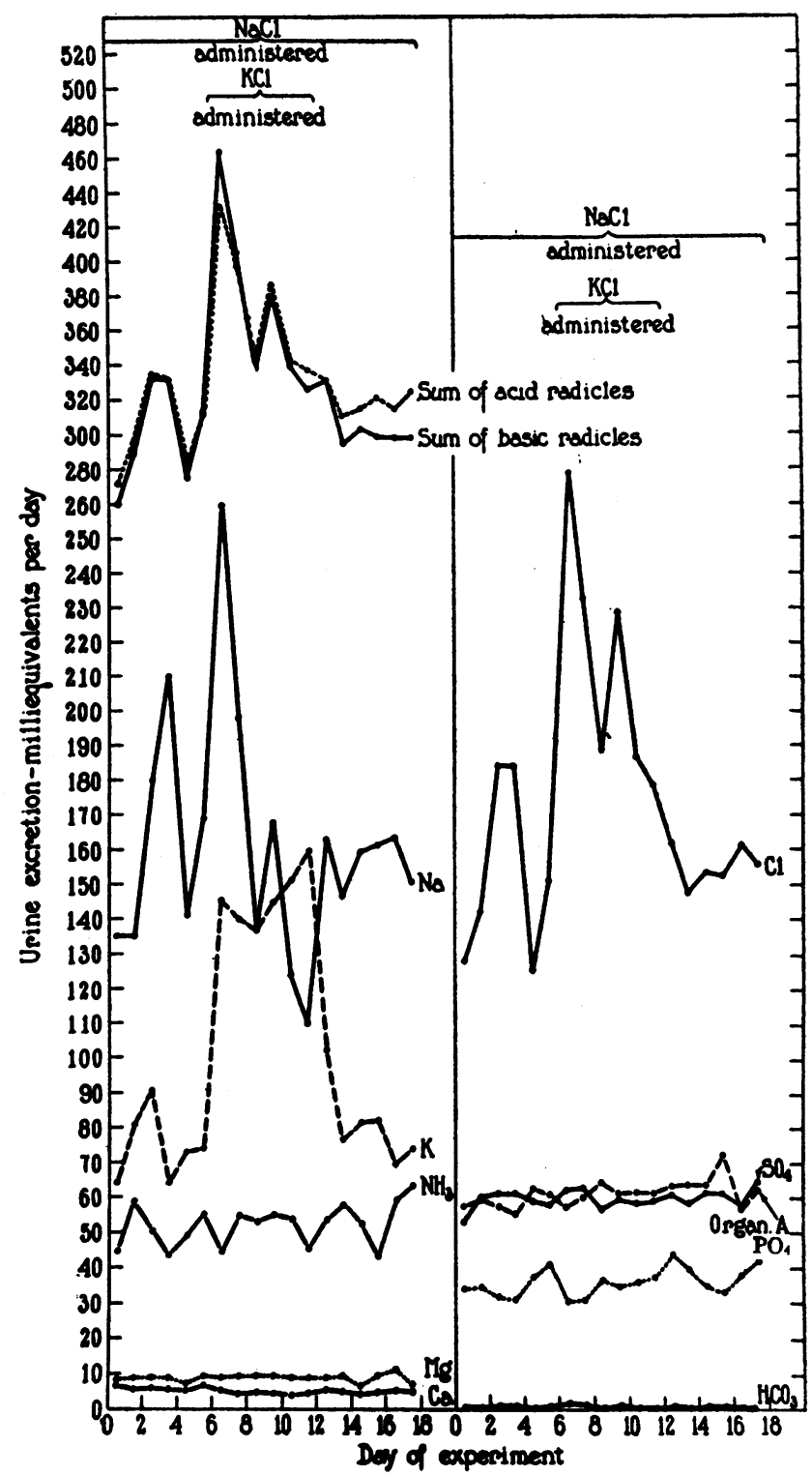

Fig. 3. Urinary Excretion of Basic and Acid RADICLES. EXPERIMENT I

These were marked off with carmine. During the first two days of the experiment carmine ( 0.2 gram) was taken with every meal, thus coloring the entire stool specimen of the period. This was repeated during each alternate 48-hour period. The preparation of the stool specimens for analysis has been described (23).

The rate of urinary excretion of each of the acid and basic radicles and of nitrogen was likewise determined before, during, and after periods in which potassium chloride was administered.

The analytical methods are described in Peters and Van Slyke (23) as follows: for urine $\mathrm{pH}$, page 792; titratable acidity, p. 828; ammonia, p. 547 ; chloride, p. 833; inorganic sulfate, p. 893 ; inorganic phosphate, p. 858; calcium, p. 425 ; magnesium, p. 779 and sodium and potassium, p. 727. For diets and feces the analytical methods are also given in Peters and Van Slyke; calcium, p. 766; magnesium, p. 784 and sodium and potassium, p. 730 . All nitrogen determinations were carried out by the usual Arnold-Gunning Kjeldahl procedure.

\section{RESULTS}

The daily balance data are presented graphically. The ordinates of the balance graphs, Figures 1, 4,6 , and 9 , represent milliequivalents of the base 


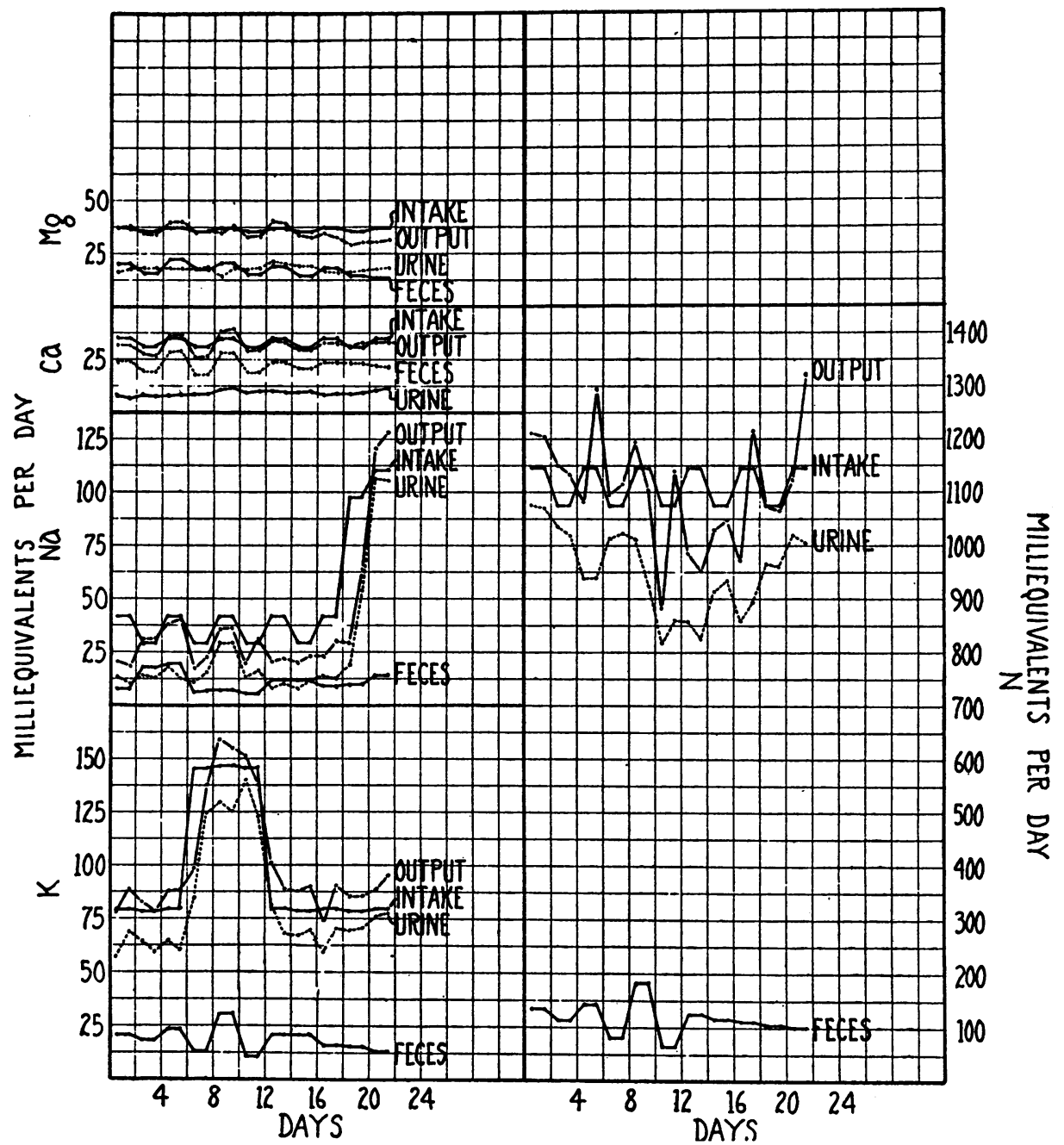

Fig. 4. Daily Balances, Experiment II, Normal Subject “M"

and nitrogen ingested or excreted each day of the. experiment. Curves are given showing the daily intake and total output. Also curves showing the division of the total output between urinary and fecal excretions are given. On days that blood samples were withdrawn, the difference between the total output and the sum of urinary and fecal excretions represents the loss of material from the body in the blood sample removed. Examination of the intake curve of each element will show the nature of the diet as regards it, how much of each element was included in the basal diet, and the periods over which added salts were given, together with the amount of base added. All added sodium and potassium were given in the form of chlorides.
The retention graphs, Figures 2 and 7, present the cumulative retention of sodium, potassium, and nitrogen compared to the weight change. The ordinate scales for weight and base retention, respectively, are so arranged as to make 150 m.eq. of base correspond with a weight change of one kilo. In order to plot nitrogen retention values conveniently on the same graph a different scale for nitrogen and base had to be used. The note at the bottom of each graph indicates the multiple of the base scale that gives milliequivalents of nitrogen. The sums of the sodium and potassium retentions are also plotted and are designated on the graphs by the letter $B$.

The ordinates of the graphs depicting the urinary excretion of acid and basic radicles, Figures 


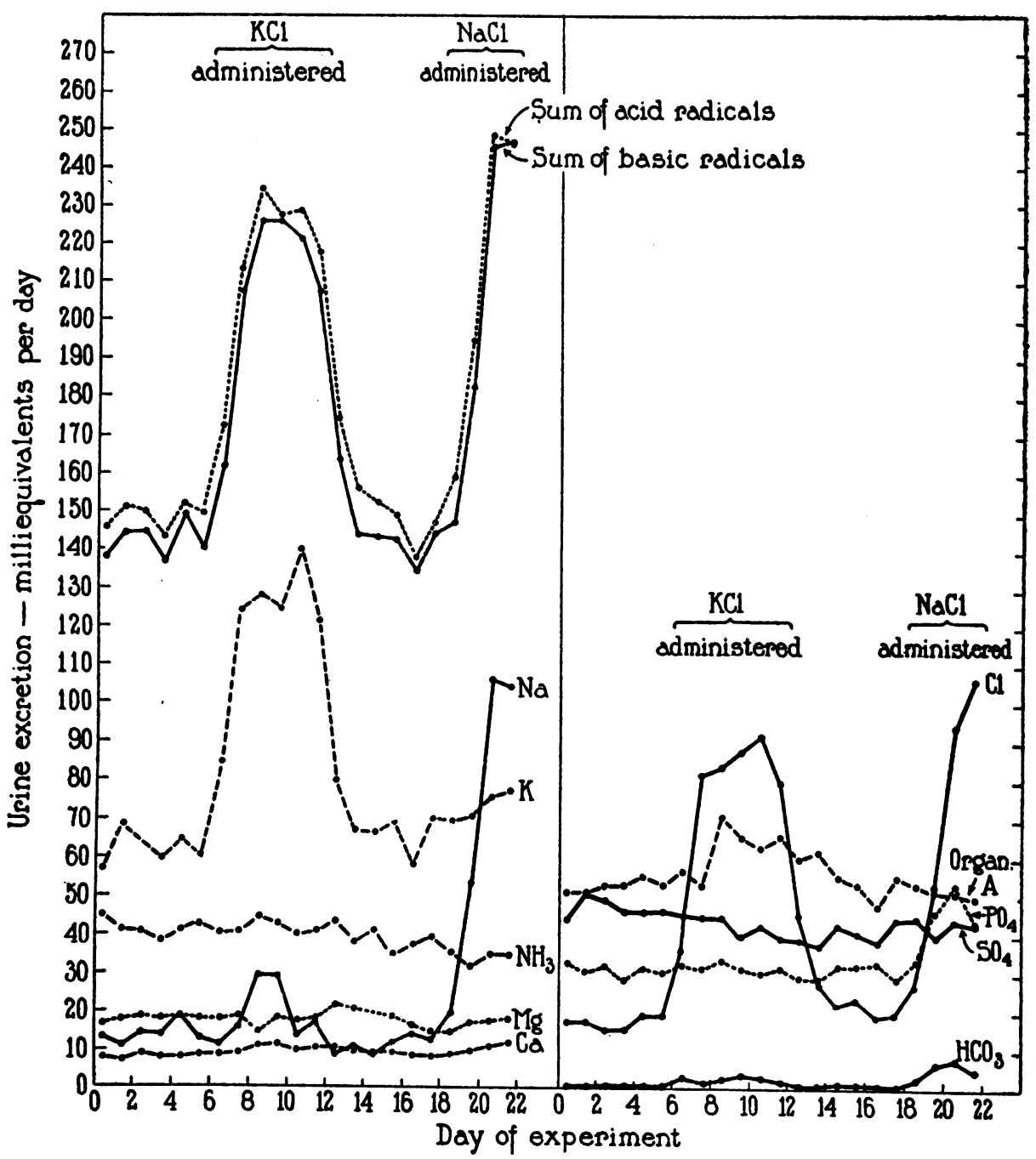

Fig. 5. Urinary Excretion of Basic and Acid Radicles, Experiment II

$3,5,8,10$, represent milliequivalents of individual and total cations and anions in 24-hour urine specimens. The sum of the total cations and sum of the total anions of the urine have been plotted in order to compare the positive and negative equivalents.

The balances of the acid radicles could not be included in the metabolism graphs as our methods of analyses of feces and food interfered with the determination of many such radicles. Furthermore, the metabolic formation of acids (e.g. of sulphuric and phosphoric acids from organic compounds of $S$ and $P$ ) renders difficult any attempt to balance total anion intake and output.
Experiment I. Normal Subject B. Weight $68 \mathrm{kgm}$. (Figures 1, 2, 3. Tables I, II.)

The subject during a six-day fore-period and eighteenday experimental period was on a diet moderately high in sodium. The daily basal diet contained an average of 202 m.eq. of sodium (equivalent to 11.7 grams of $\mathrm{NaCl}$ ). Of this total amount of sodium 68.4 m.eq. per day were derived from the addition of 4 grams of sodium chloride to the food. During Period II, 67 m.eq. of potassium, as 5 grams of potassium chloride, were added to the basal diet of Periods I and III. ${ }^{3}$

Table I summarizes the balance data per period.

Table II summarizes per period the per cent of intake

${ }^{3}$ See footnote 1, p. 924. 


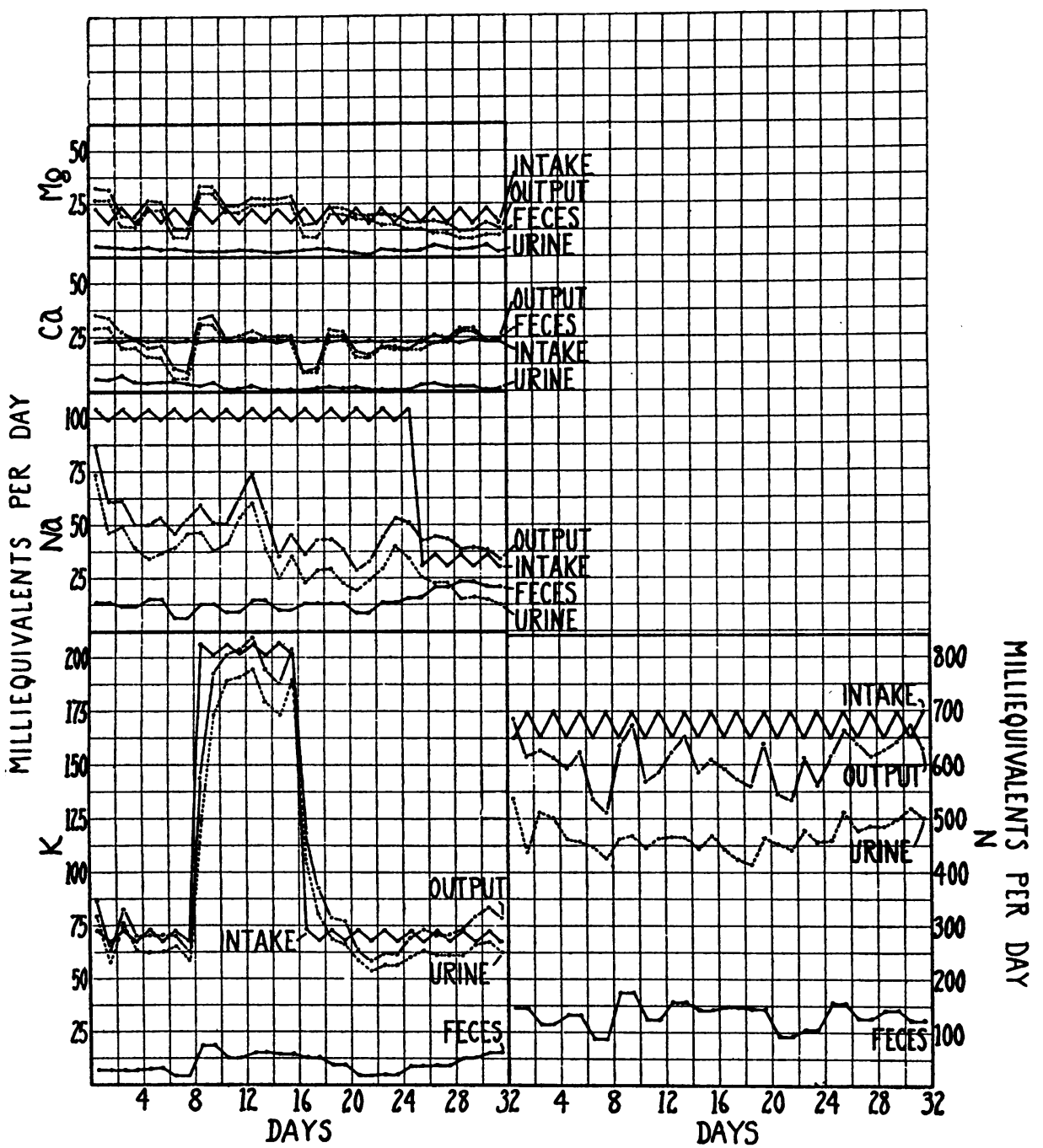

Fig. 6. Daily Balances, Experiment III, Nephrotic Patient

excreted in the urine and feces ${ }^{4}$ and the daily fecal excretion.

Experiment II. Normal Subject M. Weight $70 \mathrm{kgm}$. (Figures 2, 4, 5. Tables III, IV.)

The subject was on a moderately low sodium diet of 29 to 42 m.eq. of sodium per day, equivalent to 1.68 to 2.43 grams of $\mathrm{NaCl}$. During Period II, 67 m.eq. of potassium, as 5 grams of $\mathrm{KCl}$, were added per day to the basal diet of Periods I and III. In Period IV, 68.4 m.eq. of sodium, as 4 grams of $\mathrm{NaCl}$, were added per day to the basal diet.

4 We wish to call attention to the fact that the fecal excretion does not necessarily represent the unabsorbed portion of the ingested substance.
Experiment III. Subject K, with nephrosis. 5 (Figures $6,7,8$. Tables $V, V I, V I I$.

The subject, previous to the experiment, had been on a low salt diet to combat edema. He was nineteen years of age and when edema-free weighed approximately 59 kilos. He had at this time a urea clearance of 42 per cent of normal and a blood pressure of $130 / 80 \mathrm{~mm}$. $\mathrm{Hg}$. His serum proteins were 4.7 grams per cent, the albumin being 1.6 gram per cent. During an eight-day foreperiod and the first three experimental periods of eight days each, the patient took 68.4 m.eq. (4 grams) of sodium chloride per day in addition to the $33.2 \mathrm{~m} . e q$. of sodium in the diet, making the total daily sodium intake 102 m.eq. (equivalent to 5.9 grams of $\mathrm{NaCl}$ ). In Period

${ }^{5} \mathrm{~A}$ summary of the case history has been given by Van Slyke et al. (see Case 65 (24)). 

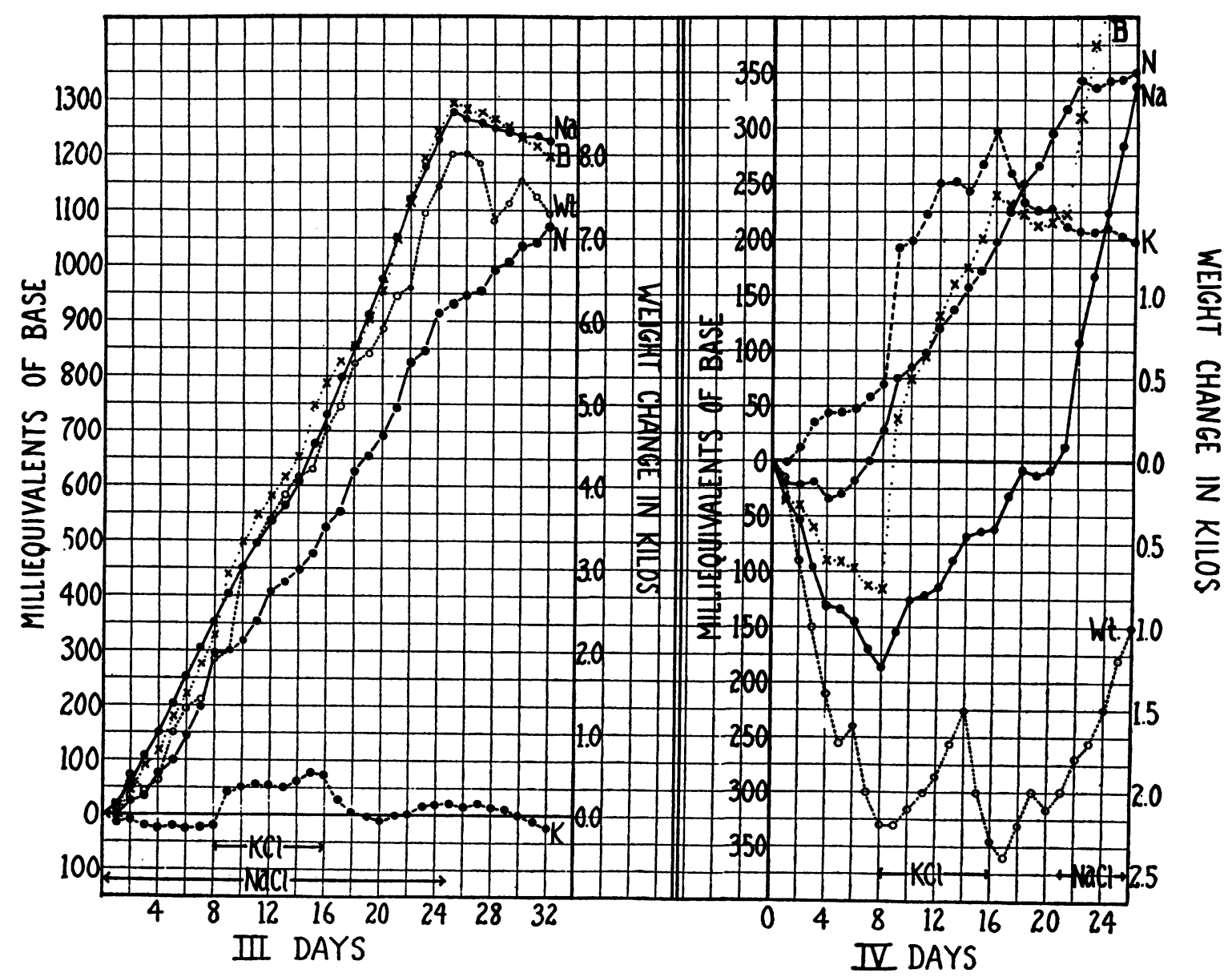

Fig. 7. Daily Cumulative Retentions, Experiments III and IV

Experiment III, m.eq. base $\times 2=$ m.eq. of nitrogen.

Experiment IV, m.eq. base $\times 4=$ m.eq. of nitrogen.

II, 134 m.eq. (10 grams) of potassium chloride were added to the diet and salt of Period I. Period III was similar to Period I. During the fourth period the basal diet without the added sodium chloride was taken.

Table VII shows the changes in the edema of this patient during the experimental period.

Experiment IV. Subject L, with terminal chronic hemorrhagic nephritis. ${ }^{6}$ (Figures 9, 7, 10. Tables VIII, IX.)

The subject was 30 years of age, and weighed 57 kilos. His urea clearance was reduced to 12 per cent of normal. His serum proteins were 5.0 grams per cent, the albumin being 2.5 grams per cent. He had moderate edema of his ankles. His blood pressure was 150/95.

During Period I the patient was given a low sodium diet averaging $28 \mathrm{~m} . e q$. of sodium or the sodium equiv-

6 A summary of the case history has been given by Van Slyke et al. (see Case 29 (24)). alent of 1.6 gram of $\mathrm{NaCl}$ per day. During Period II, $\mathrm{KCl}$ was added to the basic diet. On the first day 134 m.eq. as 10 grams of $\mathrm{KCl}$ were added. This amount resulted in such gastro-intestinal distress that the dose was reduced by half throughout the rest of the period. $\mathrm{Pe}$ riod III was the same as Period I. In Period IV, 68.4 m.eq. of sodium, as 4 grams of $\mathrm{NaCl}$, were added to the basal diet.

\section{DISCUSSION}

\section{Excretion of the added potassium chloride}

In Experiment I (a normal subject on a liberal salt intake), the potassium from the 5 grams of potassium chloride ingested per day during $\mathrm{Pe}$ riod II was excreted promptly. A negative potassium balance occurred both on the first day of potassium chloride ingestion (Figure 1) and over the entire potassium chloride period (Table I). 


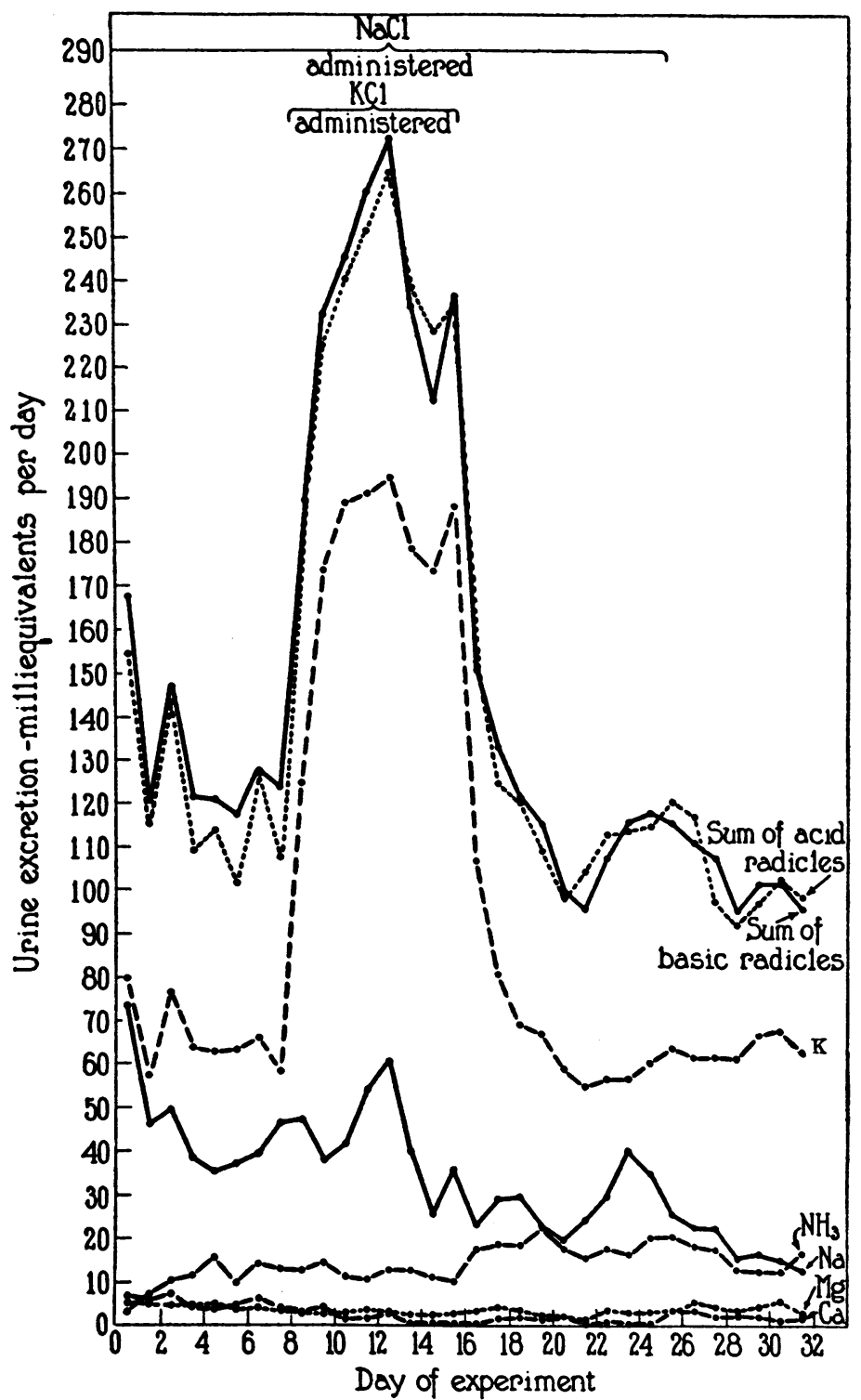

Fig. 8-a. Urinary Excretion of Basic Radicles and Sum of Acid and Basic Radicles, Experiment III

In Experiment II (a normal subject on a limited salt intake), the added potassium was not excreted promptly. A negative potassium balance did not occur until the third day of potassium chloride ingestion (Figure 4), and there was a positive potassium balance over the entire potassium chloride period (Table III).

In Experiment III (a patient with degenerative Bright's disease), the ingestion of 10 grams of potassium chloride per day resulted in relatively little potassium retention. By the second day of Period
II the potassium excretion almost equalled the intake and on the fourth day there was a negative potassium balance (Figure 6). Over the entire potassium chloride period there was a positive potassium balance of 11.8 m.eq. (Table V).

In Experiment IV (a patient with terminal hemorrhagic nephritis), the marked delay in excreting the added potassium reflected the patient's diminished kidney function. Not till the sixth day of Period II did the potassium excretion reach the intake (Figure 9), and over the eight 


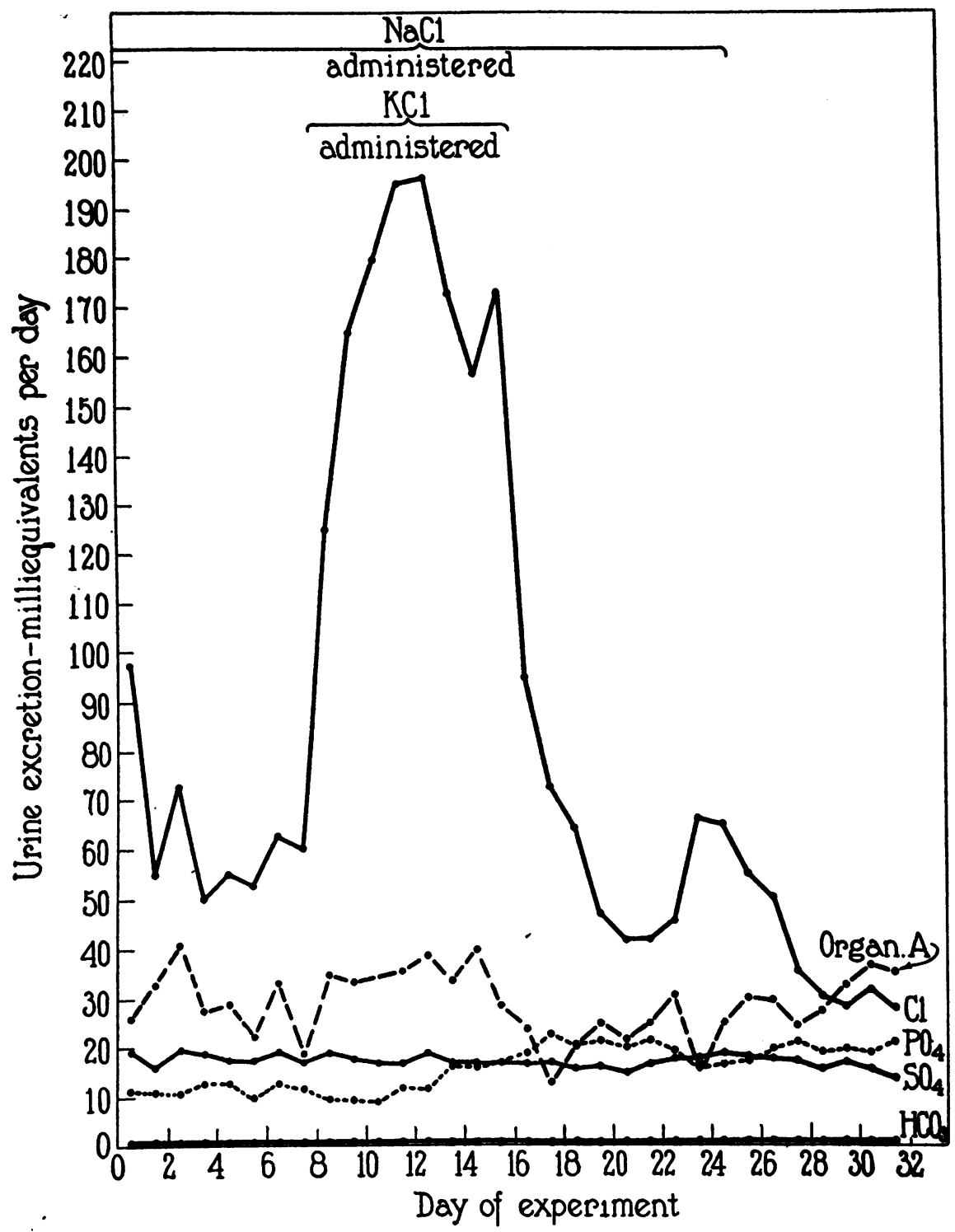

Fig. 8-b. Urinary Excretion of Acid Radicles, Experiment III

days of the period there was a retention of 28.4 m.eq. of potassium (Table VIII). This delay in excretion and the degree of potassium retention (Figure 7) is in marked contrast to the behavior observed in Experiment III.

\section{The effect of potassium chloride ingestion on the sodium balance}

(a) Normal subjects-Experiments I and II

Because of the failure to establish a constant level of sodium metabolism in Period I, Experiment $\mathrm{I}$, the effect of $\mathrm{KCl}$ on the sodium balance is not clear cut in Figure 1 and Table I. Nevertheless, it can be seen that the immediate effect of $\mathrm{KCl}$ ingestion was an increase in urinary sodium excretion to such an extent as to produce a marked negative sodium balance for the first two days of the $\mathrm{KCl}$ period (Figure 1). During the remaining four days of this period, however, sodium was retained. The retention of the last two days of the period was sufficient to compensate for the loss during the first two days, so that the average daily balance for Period II (Table I) was similar to that of Period I. 


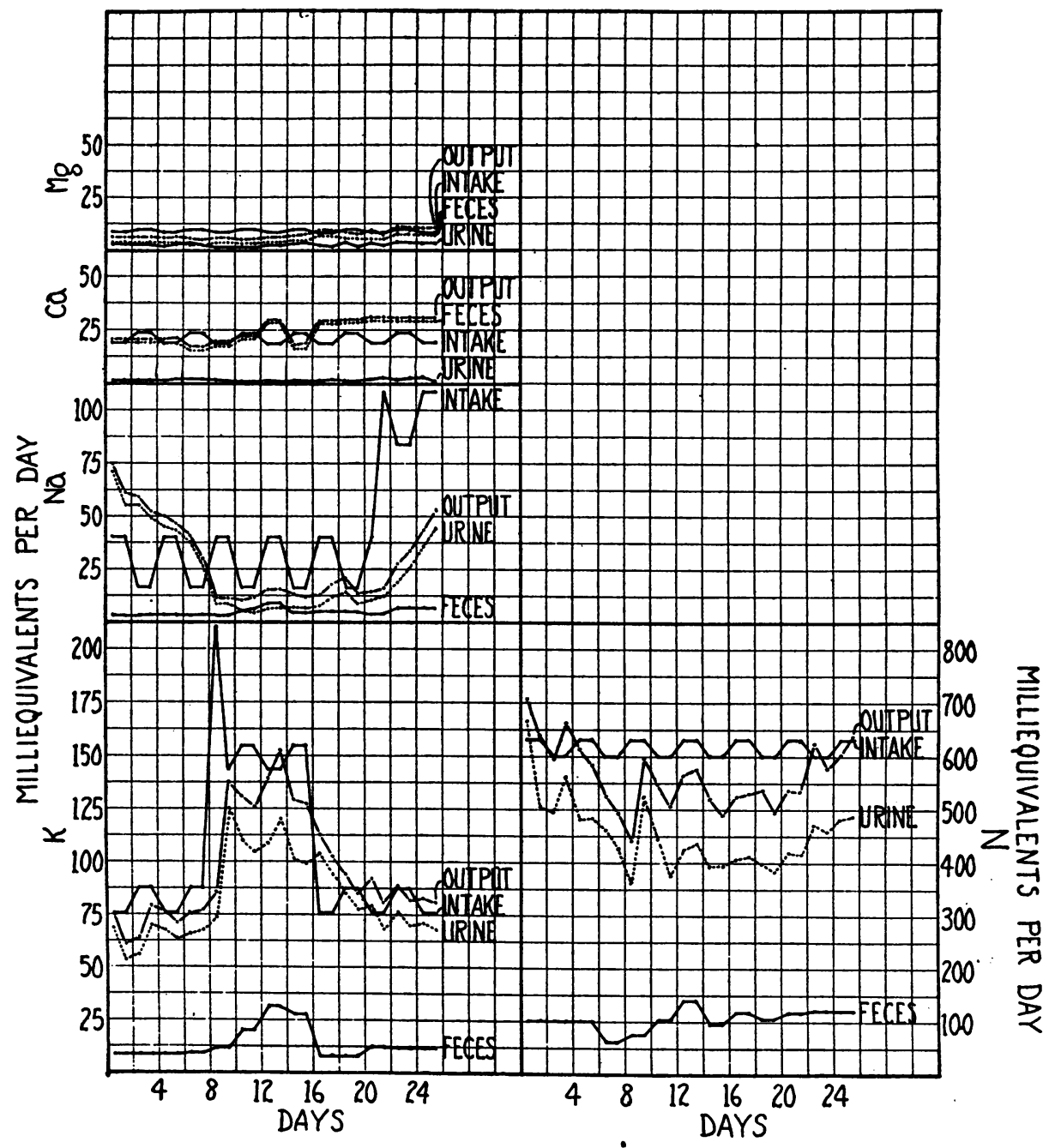

Fig. 9. Daily Balances, Experiment IV, Terminal Nephritic Patient

In contrast to Experiment I the subject in Experiment II attained approximate sodium equilibrium during Period I (Figure 4 and Table III). The ingestion of potassium chloride in Period II, Experiment II, was not accompanied by an immediate increase in urinary sodium excretion (Figure 4). However, on the third and fourth days of this period there was a definite increase in urinary sodium. The increased excretion was limited to these two days and, even during this time, the total sodium excretion did not exceed the sodium intake. The withdrawal of a $100 \mathrm{cc}$. blood sample was a factor in the negative sodium balance on the last day of the period. Column I, Table III, shows an average daily sodium balance of +6.25 m.eq. for Period II, which is but slightly lower than that of Period I.

Thus in neither of the experiments on normal subjects did the ingestion of potassium chloride appreciably increase the sodium excretion over the entire period of potassium administration.

The detailed differences in the metabolic response in the two experiments furnish an example of the necessity of considering the previous dietary history and metabolic state of the body when interpreting clinical tests or studies on mineral and water metabolism (25).

In spite of differences in the preparation of the two normal subjects, the increase in the urinary sodium that followed the feeding of potassium 


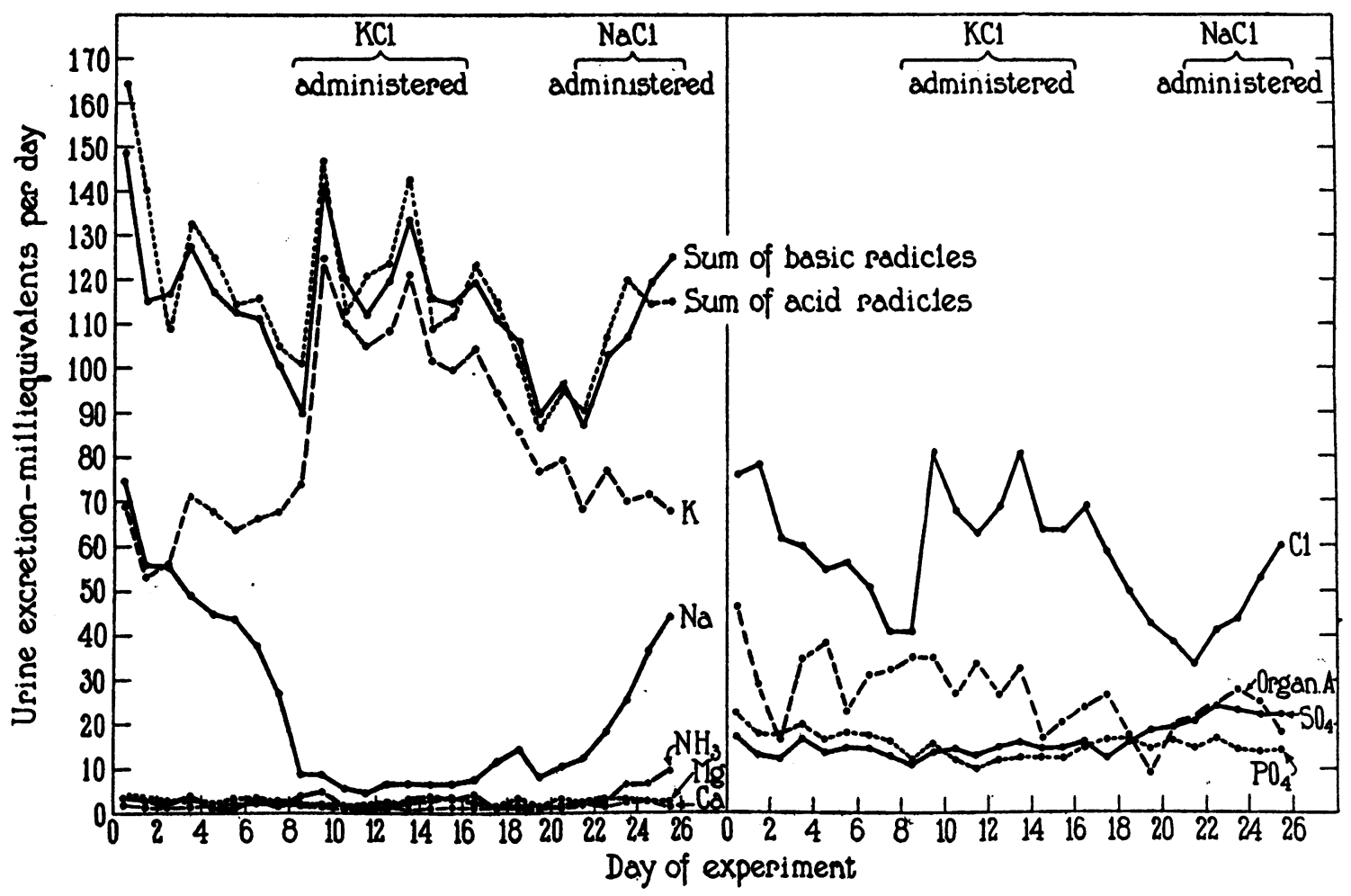

Fig. 10. Urinary Excretion of Basic and Acid Radicles, Experiment IV

chloride coincided in both with the establishment of the first negative potassium balance (Figures 1 and 4).

In Experiment II, the ingestion of the potassium chloride apparently affected the manner of sodium excretion more than the sodium balance, for the decrease in fecal sodium (Table IV) almost equalled the increase in urinary sodium. The total sodium excretion for Period II, Experiment II, was 90 per cent ${ }^{7}$ of that of Period I, while the urinary and fecal sodiums were respectively 140 and 44 per cent of the respective sodium excretion of Period I. Possibly fecal sodium in Period I was high. But using Period III as a check, we find the fecal sodium of Period II diminished by 40 per cent.

\section{(b) Nephritic subjects-Experiments III and IV}

The data of Figure 6, Experiment III, show that this patient with degenerative Bright's dis-

\footnotetext{
7 The reduction of total sodium excretion simultaneous to a lesser positive sodium balance is made possible by a slightly lower sodium intake in Period II than in Period I due to the alternating diets.
}

ease had established an approximately stable level of sodium and potassium balance during Period I. Since the positive sodium balance over Period II was slightly in excess of that of Period I (Table $\mathrm{V})$, the ingestion of potassium chloride had no appreciable effect on the sodium retention and development of edema in the patient with nephrosis. However, as in Experiments I and II, there was an increase in urinary sodium coincident to the establishment of the first negative potassium balance after the addition of potassium chloride. (Figure 6).

The restriction of sodium chloride intake in Period IV resulted in a negative sodium balance and loss of weight, and thus was more effective in reducing edema than the administration of 10 grams of potassium chloride per day.

The data of Figure 9 and Table VIII (Experiment IV) show that this nephritic patient with terminal hemorrhagic nephritis had a marked loss of sodium during Period $\mathrm{I}$ when no $\mathrm{KCl}$ was given. This occurred over a period when there was no nausea, and probably reflects the limited ability that patients with markedly reduced func- 
TABLE I

Table of balances-Experiment I, normal Subject " $B$ "

\begin{tabular}{|c|c|c|c|c|c|c|}
\hline \multirow{2}{*}{ Period } & \multicolumn{6}{|c|}{ Average balance per day } \\
\hline & $\begin{array}{c}\text { So- } \\
\text { dium }\end{array}$ & $\begin{array}{l}\text { Potas- } \\
\text { sium }\end{array}$ & $\begin{array}{l}\text { Cal- } \\
\text { cium }\end{array}$ & $\underset{\text { nesium- }}{\text { Mag- }}$ & $\begin{array}{c}\text { Nitro- } \\
\text { gen }\end{array}$ & $\begin{array}{c}\text { Nitro- } \\
\text { gen }\end{array}$ \\
\hline $\begin{array}{l}\text { I }{ }^{*} \ldots \ldots \ldots \\
\text { III } \ldots \ldots \ldots \cdots \\
\text { Entire ex- } \\
\text { periment.. }\end{array}$ & $\begin{array}{r}\text { m.eq. } \\
+26.8 \\
+28.2 \\
+36.2 \\
+30.4\end{array}$ & $\begin{array}{c}\text { m.eq. } \\
+0.15 \\
-8.12 \\
-3.00 \\
-3.66\end{array}$ & $\begin{array}{r}\text { m.eq. } \\
+6.58 \\
+6.68 \\
+4.70 \\
+5.99\end{array}$ & $\begin{array}{c}\text { m.eq. } \\
-0.57 \\
-0.78 \\
-1.98 \\
-1.11\end{array}$ & $\begin{array}{r}\text { m.eq. } \\
+68.4 \\
+77.8 \\
+71.5 \\
+72.6\end{array}$ & $\begin{array}{l}\text { grams } \\
+0.96 \\
+1.09 \\
+1.00 \\
+1.02\end{array}$ \\
\hline
\end{tabular}

* Each period six days.

TABLE II

Relative excretion of ingested base and nitrogen in urine and feces. Experiment I, normal Subject "B," 68 kilos

\begin{tabular}{|c|c|c|c|c|c|}
\hline & & $\underset{I}{\text { Period }}$ & $\begin{array}{l}\text { Period } \\
\text { II }\end{array}$ & $\begin{array}{l}\text { Period } \\
\text { III }\end{array}$ & $\underset{\text { ager- }}{\text { Aver- }}$ \\
\hline Sodium. & $\begin{array}{l}\text { Total intake per day, m.eq. } \\
\text { Per coint of intake in urine } \\
\text { Per cent of intake in foces } \\
\text { Fecal excretion per day, m.eq. }\end{array}$ & $\begin{array}{c}201 \\
81 \\
5.3 \\
11.0\end{array}$ & $\begin{array}{c}204 \\
80 \\
3.8 \\
7.8\end{array}$ & $\begin{array}{c}201 \\
78 \\
2.9 \\
5.9\end{array}$ & $\begin{array}{c}202 \\
80 \\
4.0 \\
8.2\end{array}$ \\
\hline Potassium.. & $\begin{array}{l}\text { Total intake per day, m.eq. } \\
\text { Per cent of intake in urine } \\
\text { Per cent of intake in feces } \\
\text { Fecal excretion per day, m.eq. }\end{array}$ & $\begin{array}{l}86 \\
86 \\
13.0 \\
11.0\end{array}$ & $\begin{array}{c}148 \\
99 \\
6.1 \\
9.1\end{array}$ & $\begin{array}{l}86 \\
94 \\
9.0 \\
7.8\end{array}$ & $\begin{array}{c}107 \\
93 \\
9.4 \\
9.3\end{array}$ \\
\hline Calcium.... & $\begin{array}{l}\text { Total intake per day, m.eq. } \\
\text { Per cent of intake in urine } \\
\text { Per cent of intake in foces } \\
\text { Fecal excretion per day, m.eq. }\end{array}$ & $\begin{array}{l}55 \\
11 \\
77 \\
42\end{array}$ & $\begin{array}{r}49 \\
9 \\
77 \\
38\end{array}$ & $\begin{array}{l}65 \\
9 \\
82 \\
45\end{array}$ & $\begin{array}{l}53 \\
10 \\
79 \\
42\end{array}$ \\
\hline Magnesium. & $\begin{array}{l}\text { Total intake per day, m.eq. } \\
\text { Per cent of intake in urine } \\
\text { Per cont of intake in feces } \\
\text { Fecal exeretion per day, m.eq. }\end{array}$ & $\begin{array}{l}33 \\
26 \\
76 \\
25\end{array}$ & $\begin{array}{l}31 \\
29 \\
73 \\
23\end{array}$ & $\begin{array}{l}33 \\
27 \\
79 \\
26\end{array}$ & $\begin{array}{l}32 \\
27 \\
76 \\
25\end{array}$ \\
\hline Nitrogen. . & \begin{tabular}{|l|} 
Intake per day, grams \\
Per cent of intake in feces \\
Fecal ezcretion per day, grama \\
Grams fecal N X 70 \\
Weight in kilos
\end{tabular} & $\begin{array}{c}19.7 \\
8.8 \\
1.74 \\
1.79\end{array}$ & $\begin{array}{l}19.7 \\
7.0 \\
1.38 \\
1.42\end{array}$ & $\begin{array}{l}19.7 \\
7.7 \\
1.52 \\
1.57\end{array}$ & $\begin{array}{c}19.7 \\
7.8 \\
1.55 \\
1.60\end{array}$ \\
\hline
\end{tabular}

tioning renal tissue have to limit sodium and chloride excretion when the salt intake is low, even though the serum sodium and chloride concentrations are below normal levels (26). Coincident with this negative sodium balance there was a marked loss of weight (Figure 7, Experiment IV) and a loss of edema.

The subsequent ingestion of the potassium chloride by this patient resulted in no increase in urinary sodium. Indeed, from the retention graph (Figure 7), it would seem as though the retention of potassium chloride had been accompanied by a retention of sodium. Though the daily dose of potassium chloride was small (5 grams), it was probably as large a dose as could safely be administered to this patient. We have, therefore, in this experiment, as in Experiment III, evidence that potassium chloride administration is of less therapeutic value in treating edema than is sodium chloride restriction.

\section{Correlation between base retention and weight changes}

Analyses of serum base, sodium, and potassium in Experiments I and II, already published (27), showed variations from period to period hardly

TABLE III

Table of balances-Experiment II, normal Subject " $M$ "

\begin{tabular}{|c|c|c|c|c|c|c|}
\hline \multirow{2}{*}{ Period } & \multicolumn{6}{|c|}{ Average balance per day } \\
\hline & $\begin{array}{c}\text { So- } \\
\text { dium }\end{array}$ & $\begin{array}{l}\text { Potas- } \\
\text { sium }\end{array}$ & $\begin{array}{l}\text { Cal- } \\
\text { cium }\end{array}$ & $\begin{array}{c}\text { Mag- } \\
\text { nesium }\end{array}$ & $\underset{\text { gen }}{\text { Nitro- }}$ & $\begin{array}{c}\text { Nitro- } \\
\text { gen }\end{array}$ \\
\hline $\begin{array}{l}I^{*} I^{*} \ldots \ldots \\
I_{I V} I^{*} \ldots \\
I^{*} \ldots\end{array}$ & $\begin{array}{r}\text { m.eq. } \\
+7.54 \\
+\quad 6.25 \\
+14.47 \\
+18.57\end{array}$ & $\begin{array}{c}\text { m.eq. } \\
-4.50 \\
+\quad 5.83 \\
-\quad 9.53 \\
-10.25\end{array}$ & $\begin{array}{r}\text { m.eq. } \\
+1.83 \\
+0.75 \\
+1.35 \\
+0.22\end{array}$ & $\begin{array}{c}\text { m.eq. } \\
-0.58 \\
+1.18 \\
+1.07 \\
+5.98\end{array}$ & $\begin{array}{c}\text { m.eq. } \\
-57.80 \\
+9.00 \\
+87.00 \\
-36.20\end{array}$ & $\begin{array}{l}\text { grams } \\
-0.81 \\
+0.13 \\
+1.22 \\
-0.51\end{array}$ \\
\hline $\begin{array}{l}\text { Total ex- } \\
\text { periment }\end{array}$ & +11.08 & -4.1 & +1.13 & +1.54 & +3.82 & +0.05 \\
\hline
\end{tabular}

* Six day period.

* Four days instead of six.

TABLE IV

Relative excretion of ingested base and nitrogen in urine and feces. Experiment II, normal Subject " $M$," 70 kilos

\begin{tabular}{|c|c|c|c|c|c|c|}
\hline & & $\underset{I}{\text { Period }}$ & Period & $\begin{array}{c}\text { Period } \\
\text { III }\end{array}$ & $\begin{array}{c}\text { Period } \\
\text { IV }\end{array}$ & $\begin{array}{c}\text { Aver- } \\
\text { age }\end{array}$ \\
\hline Bodium.... & $\begin{array}{l}\text { Total intake per day, m.eq. } \\
\text { Per cent of intake in urine } \\
\text { Per cent of intake in feces } \\
\text { Fecal excretion per day, } \\
\text { m.eq. }\end{array}$ & $\begin{array}{l}38 \\
37 \\
40 \\
15\end{array}$ & $\begin{array}{c}33 \\
58 \\
19 \\
6.4\end{array}$ & $\begin{array}{l}38 \\
29 \\
29 \\
11\end{array}$ & $\begin{array}{r}104 \\
69 \\
12 \\
12\end{array}$ & $\begin{array}{l}49 \\
46 \\
26 \\
11\end{array}$ \\
\hline Potasaium. & $\begin{array}{l}\text { Total intake per day, m.eq. } \\
\text { Per cent of intake in urine } \\
\text { Per cent of intake in feces } \\
\text { Fecal exeretion per day, } \\
\text { m.ex. }\end{array}$ & $\begin{array}{l}79 \\
79 \\
26 \\
21\end{array}$ & $\begin{array}{r}146 \\
83 \\
13 \\
18\end{array}$ & $\begin{array}{l}79 \\
87 \\
24 \\
19\end{array}$ & $\begin{array}{l}79 \\
93 \\
18 \\
14\end{array}$ & $\begin{array}{l}97 \\
85 \\
20 \\
18\end{array}$ \\
\hline Calcium... & $\begin{array}{l}\text { Total intake per day, m.eq. } \\
\text { Per cent of intake in urine } \\
\text { Per cent of intake in feces } \\
\text { Fecal excretion per day. } \\
\text { m.eq. }\end{array}$ & $\begin{array}{l}34 \\
23 \\
72 \\
24\end{array}$ & $\begin{array}{l}32 \\
30 \\
68 \\
22\end{array}$ & $\begin{array}{l}34 \\
27 \\
69 \\
23\end{array}$ & $\begin{array}{l}33 \\
30 \\
69 \\
23\end{array}$ & $\begin{array}{l}33 \\
28 \\
70 \\
23\end{array}$ \\
\hline Magnesium. & $\begin{array}{l}\text { Total intake per day. m.eq. } \\
\text { Per cent of intake in urine } \\
\text { Per cent of intake in feces } \\
\text { Fecal excretion per day, } \\
\text { m.eq. }\end{array}$ & $\begin{array}{l}37 \\
49 \\
54 \\
20\end{array}$ & $\begin{array}{l}36 \\
48 \\
49 \\
18\end{array}$ & $\begin{array}{l}37 \\
51 \\
46 \\
17\end{array}$ & $\begin{array}{l}37 \\
46 \\
38 \\
14\end{array}$ & $\begin{array}{l}37 \\
49 \\
48 \\
18\end{array}$ \\
\hline Nitrogen... & $\begin{array}{l}\text { Intake per day, grams } \\
\text { Per cent of intake in feces } \\
\text { Fecal excretion per day, } \\
\text { grams } \\
\text { Grams fecal N X } 70 \\
\text { Weight in kilos }\end{array}$ & $\begin{array}{c}15.7 \\
11.0 \\
1.82 \\
1.82\end{array}$ & $\begin{array}{c}15.4 \\
10.0 \\
1.54 \\
1.54\end{array}$ & $\begin{array}{c}15.7 \\
11.0 \\
1.65 \\
1.65\end{array}$ & $\begin{array}{c}15.5 \\
9.3 \\
1.44 \\
1.44\end{array}$ & $\begin{array}{c}15.6 \\
10.0 \\
1.63 \\
1.63\end{array}$ \\
\hline
\end{tabular}

* Four days instead of six. 
TABLE V

Table of balances. Experiment III, nephrotic Patient " $K$ "

\begin{tabular}{|c|c|c|c|c|c|c|}
\hline \multirow{2}{*}{ Period } & \multicolumn{6}{|c|}{ Average daily balance } \\
\hline & $\begin{array}{c}\text { So- } \\
\text { dium }\end{array}$ & $\begin{array}{l}\text { Potas- } \\
\text { sium }\end{array}$ & $\begin{array}{c}\text { Cal- } \\
\text { cium }\end{array}$ & $\begin{array}{c}\text { Mag- } \\
\text { nesium }\end{array}$ & $\underset{\text { Nen }}{\text { Nitro- }}$ & $\underset{\text { gen }}{\text { Nitro- }}$ \\
\hline $\begin{array}{l}\text { I } \ldots \ldots \ldots \\
\text { III } \ldots \ldots \\
\text { II }_{I V * *}^{*} \ldots\end{array}$ & $\begin{array}{c}\text { m.eq. } \\
+44.20 \\
+47.10 \\
+60.80 \\
-7.14\end{array}$ & $\begin{array}{c}\text { m.eq. } \\
-2.42 \\
+11.80 \\
-\quad 5.61 \\
-\quad 6.53\end{array}$ & $\begin{array}{c}\text { m.eq. } \\
+0.19 \\
-4.34 \\
+4.14 \\
-2.53\end{array}$ & $\begin{array}{c}\text { m.eq. } \\
-3.14 \\
-8.78 \\
+1.23 \\
+4.30\end{array}$ & $\begin{array}{r}\text { m.eq. } \\
+73.4 \\
+57.5 \\
+93.8 \\
+37.7\end{array}$ & $\begin{array}{l}\text { grams } \\
+1.03 \\
+0.80 \\
+1.31 \\
+0.53\end{array}$ \\
\hline Total. & +38.40 & -0.66 & -0.43 & -1.69 & +67.4 & +0.94 \\
\hline
\end{tabular}

* 9 days instead of 8 .

** 7 days instead of 8 .

greater than the experimental errors of the methods. It, therefore, appears probable that changes in concentration of extracellular body fluids did not account for any important part of the sodium and potassium retentions and losses in Experiments I and II.

During the first eleven days of Experiment I there was a close correlation between the sum of sodium and potassium retentions and weight changes corresponding to the ratio of 150 milliequivalents of base per kilo weight change (Figure 2). The data indicate an approximate constancy of base concentration in the body fluids and a major part of the weight changes to be due to changes in extracellular body fluid volume.

Over the last seven days of Experiment I (Figure 2) the correlation between base retention and weight change ceased, base retention occurring without an equivalent weight increase. This behavior exemplifies the result of an acute upper respiratory infection. The subject developed a severe cold on the thirteenth day of the experiment. On the fourteenth day he had a sore throat and on the fifteenth day went to bed with a fever.
TABLE VI

Relative excretion of ingested base and nitrogen in urine and feces. Experiment III, nephrotic Patient " $K$," 59 kilos

\begin{tabular}{|c|c|c|c|c|c|c|}
\hline & & $\underset{\text { Period }}{\text { I }}$ & $\begin{array}{c}\text { Period } \\
\text { II }\end{array}$ & $\begin{array}{c}\text { Period } \\
\text { III }\end{array}$ & $\begin{array}{c}\text { Period } \\
\text { IV }\end{array}$ & $\begin{array}{c}\text { Aver- } \\
\text { age }\end{array}$ \\
\hline Sodium.... & $\begin{array}{l}\text { Total intake per day, m.eq. } \\
\text { Per cent of intake in urine } \\
\text { Per cent of intake in feces } \\
\text { Fecal excretion per day, } \\
\text { m.eq. }\end{array}$ & $\begin{array}{r}102 \\
45 \\
11 \\
12\end{array}$ & $\begin{array}{r}102 \\
42 \\
12 \\
12\end{array}$ & $\begin{array}{r}102 \\
27 \\
13 \\
13\end{array}$ & $\begin{array}{l}33 \\
57 \\
64 \\
21\end{array}$ & $\begin{array}{l}87 \\
42 \\
23 \\
14\end{array}$ \\
\hline Potassium. . & $\begin{array}{l}\text { Total intake per day, m.eq. } \\
\text { Per cent of intake in urine } \\
\text { Per cent of intake in feces } \\
\text { Fecal excretion per day, } \\
\text { m.eq. }\end{array}$ & $\begin{array}{l}70 \\
94 \\
9.2 \\
6.4\end{array}$ & $\begin{array}{c}204 \\
87 \\
7.4 \\
15.0\end{array}$ & $\begin{array}{l}70 \\
96 \\
12.0 \\
8.1\end{array}$ & $\begin{array}{l}69 \\
91 \\
18 \\
12\end{array}$ & $\begin{array}{r}103 \\
92 \\
11 \\
10\end{array}$ \\
\hline Calcium... . & $\begin{array}{l}\text { Total intake per day, m.eq. } \\
\text { Per cent of intake in urine } \\
\text { Per cent of intake in feces } \\
\text { Fecal excretion per day, } \\
\text { m.eq. }\end{array}$ & $\begin{array}{l}23 \\
21 \\
78 \\
18\end{array}$ & $\begin{array}{c}23 \\
7.4 \\
112 \\
26\end{array}$ & $\begin{array}{c}23 \\
3.8 \\
78 \\
18\end{array}$ & $\begin{array}{c}23 \\
9.2 \\
96 \\
22\end{array}$ & $\begin{array}{l}23 \\
10 \\
91 \\
21\end{array}$ \\
\hline Magnegium. & $\begin{array}{l}\text { Total intake per day, m.eq. } \\
\text { Per cent of intake in urine } \\
\text { Per cent of intake in feces } \\
\text { Fecal excretion per day, } \\
\text { m.eq. }\end{array}$ & $\begin{array}{l}20 \\
22 \\
94 \\
18\end{array}$ & $\begin{array}{r}20 \\
14 \\
130 \\
26\end{array}$ & $\begin{array}{l}20 \\
14 \\
80 \\
16\end{array}$ & $\begin{array}{l}19 \\
22 \\
56 \\
11\end{array}$ & $\begin{array}{l}20 \\
18 \\
91 \\
18\end{array}$ \\
\hline Nitrogen... & $\begin{array}{l}\text { Intake per day, grams } \\
\text { Per cent of intake in feces } \\
\text { Fecal excretion per day, } \\
\text { grams } \\
\frac{\text { Grams fecal } \mathrm{N} \times 70}{\text { Weight in kilos }}\end{array}$ & $\begin{array}{r}9.44 \\
18.00 \\
1.69 \\
\\
2.01\end{array}$ & $\begin{array}{r}9.44 \\
22.00 \\
2.09 \\
\\
2.48\end{array}$ & $\begin{array}{r}9.42 \\
19.00 \\
1.77 \\
\\
2.10\end{array}$ & $\begin{array}{r}9.50 \\
20.00 \\
1.89 \\
2.24\end{array}$ & $\begin{array}{r}9.44 \\
20.00 \\
1.85 \\
\\
2.20\end{array}$ \\
\hline
\end{tabular}

This event gave an unexpected opportunity for observing the inorganic metabolism during the onset of such an infection. The retention of base over this period was not accompanied by a parallel increase in weight, apparently because an increase in sodium retention occurred without a corresponding increase in extracellular fluid. The retention of sodium was similar to that of chloride reported by Sunderman (28) and of fixed base by Austin and Sunderman (29) in studies on pneumonia patients receiving a liberal sodium chloride intake.

During Period I of Experiment II the retention data (Figure 2) show a correlation between the sum of the potassium and sodium retentions and weight change. During the $\mathrm{KCl}$ period, i.e. Pe-

TABLE VII

Characterization of edema of nephrotic Patient, " $K$," Experiment III

\begin{tabular}{|c|c|c|c|c|c|c|c|}
\hline Period * & Arms & Face & Legs & Scrotum & Back & Thorax & Abdomen \\
\hline $\begin{array}{l}\text { Fore } \ldots \ldots \ldots \\
\text { I } \ldots \ldots \ldots \\
\text { II } \ldots \ldots \ldots \ldots \\
\text { III } \ldots \ldots \ldots \ldots \\
\text { IV } \ldots \ldots \ldots\end{array}$ & $\begin{array}{c}0 \\
+ \\
+t \\
++t \\
++\end{array}$ & $\begin{array}{c}t \\
++ \\
++t \\
++++ \\
+++\end{array}$ & $\begin{array}{c}+t \\
++++ \\
+++++ \\
++++++ \\
+++++\end{array}$ & $\begin{array}{c}0 \\
+ \\
+t \\
++t \\
+t\end{array}$ & + & $\begin{array}{c} \pm \\
t+ \\
++t \\
++t \\
++\end{array}$ & $\begin{array}{c} \pm \\
+t \\
+++t \\
++++t \\
++++\end{array}$ \\
\hline
\end{tabular}

* Characterization at end of each period given. 
TABLE VIII

Table of balances. Experiment IV, nephritic Subject " $L$ "

\begin{tabular}{|c|c|c|c|c|c|c|}
\hline \multirow{2}{*}{ Period } & \multicolumn{6}{|c|}{ Average daily balance } \\
\hline & $\begin{array}{l}\text { So- } \\
\text { dium }\end{array}$ & $\begin{array}{l}\text { Potas- } \\
\text { sium }\end{array}$ & $\begin{array}{c}\text { Cal- } \\
\text { cium }\end{array}$ & $\underset{\text { nesium }}{\text { Mag- }}$ & $\begin{array}{c}\text { Nitro- } \\
\text { gen }\end{array}$ & $\begin{array}{l}\text { Nitro- } \\
\text { gen }\end{array}$ \\
\hline $\begin{array}{l}\operatorname{I} \ldots \ldots \ldots \\
\operatorname{III}_{I} \ldots \ldots \\
\operatorname{IV}^{*} \ldots \ldots\end{array}$ & $\begin{array}{l}\text { m.eq. } \\
-23.3 \\
+15.8 \\
+15.1 \\
+64.6\end{array}$ & $\begin{array}{r}\text { m.eq. } \\
+\quad 8.60 \\
+28.40 \\
-17.00 \\
-\quad 2.76\end{array}$ & $\begin{array}{l}\text { m.eq. } \\
+1.80 \\
-0.95 \\
-9.00 \\
-5.56\end{array}$ & $\begin{array}{r}\text { m.eq. } \\
+2.78 \\
+2.99 \\
+0.12 \\
-1.24\end{array}$ & $\begin{array}{r}\text { m.eq. } \\
+14.1 \\
+85.5 \\
+95.4 \\
+24.2\end{array}$ & $\begin{array}{l}\text { grams } \\
+0.20 \\
+1.20 \\
+1.34 \\
+0.34\end{array}$ \\
\hline Total.... & +13.0 & +7.58 & -2.54 & +1.94 & +63.6 & +0.75 \\
\hline
\end{tabular}

* 5 days instead of 8 .

TABLE IX

Relative excretion of ingested base and nitrogen in urine and feces. Experiment IV, nephritic Patient " $L$," 57 kilos

\begin{tabular}{|c|c|c|c|c|c|c|}
\hline & & $\underset{I}{\text { Period }}$ & $\begin{array}{c}\text { Period } \\
\text { II }\end{array}$ & $\begin{array}{c}\text { Period } \\
\text { III }\end{array}$ & $\begin{array}{c}\text { Period } \\
\text { IV }\end{array}$ & $\begin{array}{c}\text { A ver- } \\
\text { age }\end{array}$ \\
\hline Sodium.... & $\begin{array}{l}\text { Total intake per day, m.eq. } \\
\text { Per cent of intake in urine } \\
\text { Per cent of intake in feces } \\
\text { Fecal excretion per day, } \\
\text { m.eq. }\end{array}$ & $\begin{array}{c}28 \\
170 \\
12.0 \\
3.3\end{array}$ & $\begin{array}{l}28 \\
24 \\
19.0 \\
5.4\end{array}$ & $\begin{array}{c}31 \\
34 \\
16.0 \\
4.8\end{array}$ & $\begin{array}{c}99 \\
28 \\
6.5 \\
6.4\end{array}$ & $\begin{array}{l}42 \\
57 \\
11.0 \\
4.8\end{array}$ \\
\hline Potassium. . & $\begin{array}{l}\text { Total intake per day, m.eq. } \\
\text { Per cent of intake in urine } \\
\text { Per cent of intake in feces } \\
\text { Fecal excretion per day, } \\
\text { m.eq. }\end{array}$ & $\begin{array}{c}82 \\
79 \\
11 \\
8.7\end{array}$ & $\begin{array}{r}157 \\
67 \\
15 \\
23\end{array}$ & $\begin{array}{c}81 \\
110 \\
11 \\
9.2\end{array}$ & $\begin{array}{l}81 \\
88 \\
15 \\
12\end{array}$ & $\begin{array}{c}104.5 \\
79 \\
13 \\
14\end{array}$ \\
\hline Calcium... & $\begin{array}{l}\text { Total intake per day, m.eq. } \\
\text { Per cent of intake in urine } \\
\text { Per cent of intake in feces } \\
\text { Fecal exeretion per day, } \\
\text { m.eq. }\end{array}$ & $\begin{array}{l}21 \\
7.4 \\
84 \\
18\end{array}$ & $\begin{array}{c}21 \\
5.4 \\
98 \\
21\end{array}$ & $\begin{array}{c}21 \\
6.6 \\
136 \\
29\end{array}$ & $\begin{array}{c}21 \\
9.8 \\
140 \\
29\end{array}$ & $\begin{array}{c}21 \\
7.0 \\
109 \\
23\end{array}$ \\
\hline Magnesium. & $\begin{array}{l}\text { Total intake per day, m.eq. } \\
\text { Per cent of intake in urine } \\
\text { Per cent of intake in feces } \\
\text { Fecal excretion per day, } \\
\text { m.eq. }\end{array}$ & $\begin{array}{r}8.8 \\
31.0 \\
\mathbf{3 7 . 0} \\
\mathbf{3 . 3}\end{array}$ & $\begin{array}{r}8.8 \\
26.0 \\
40.0 \\
3.5\end{array}$ & $\begin{array}{r}8.7 \\
28.0 \\
70.0 \\
6.1\end{array}$ & $\begin{array}{r}8.7 \\
33.0 \\
81.0 \\
7.0\end{array}$ & $\begin{array}{r}8.8 \\
29.0 \\
53.0 \\
4.6\end{array}$ \\
\hline Nitrogen. : . & $\begin{array}{l}\text { Intake per day, orams } \\
\text { Per cent of intake in feces } \\
\text { Fecal excretion per day, } \\
\text { grams } \\
\frac{\text { Grams fecal N X 70 }}{\text { Weight in kilos }}\end{array}$ & $\begin{array}{r}8.6 \\
15.0 \\
1.3 \\
1.60\end{array}$ & $\begin{array}{r}8.6 \\
17.0 \\
1.5 \\
1.84\end{array}$ & $\begin{array}{r}8.7 \\
18.0 \\
1.6 \\
1.96\end{array}$ & $\begin{array}{r}8.7 \\
19.0 \\
1.7 \\
\\
2.09\end{array}$ & $\begin{array}{r}8.6 \\
17.0 \\
1.5 \\
\\
1.84\end{array}$ \\
\hline
\end{tabular}

riod II, the increase in weight was greater than could be accounted for by the retention of base with a concentration of 150 milliequivalents per liter of body fluid. In the absence of a decrease in plasma sodium and potassium (27), this lack of correlation between base and fluid retentions may have been due to a dilution of intracellular base. During Period III there was a decrease in weight without a corresponding decrease in base. The excess loss in weight over base in Period III approximately equalled the excess increase in weight over base retention in Period II. In Period IV the retention of sodium and increase in weight showed a correlation indicative of extracellular fluid retention.

The retention data of Experiment III (Figure 7) show a close correlation between base retention and weight changes on the basis of 150 milliequivalents of base per liter of body fluid. Since the sodium and base retentions were very nearly the same, except over Period II, and since the correlation between sodium retentions and weight changes was as good as that between base retention and weight change, the data indicate that the weight changes in this experiment are due to extracellular fluid changes, unless there has been a change in the permeability of cell membranes to sodium $(30,31)$.

The retention data of Experiment IV (Figure 7) show some correlation between sodium retention and weight change, but no such clear correlation as shown in Experiment III. There is no clear relation between potassium retention and weight change. Nor is there any discernible relation between the retention of sodium plus potassium and weight change that explains the discrepancies between base retention and water balance. Since we did not have plasma base analyses on this patient we cannot consider the effects of changing plasma base concentrations on the water balance. The balance data, however, would suggest plasma concentration changes, and support the known fact that such patients are unable to maintain normal base concentrations.

\section{Urinary excretion of acids and bases}

The approximate constancy of the urinary ammonia and bicarbonate in Experiments I, II, and III indicate that the $\mathrm{KCl}$ caused little if any disturbance of the acid-base equilibrium such as has been reported by others (10). In Experiment IV the relatively constant urinary bicarbonate, ${ }^{8} \mathrm{pH}$, and ammonia is not necessarily an index of little disturbance in acid-base balance inasmuch as it may reflect the inability of the kidneys to alter the concentrations of these urinary constituents to any great extent.

The sum of the total cations and sum of the

8 The $\mathrm{pH}$ of these urines varied from 5.3 to 5.4 and at this acidity the bicarbonate was so low that it has been omitted from Figure 10. 
total anions in the daily urines of each of the four experiments (Figures 3, 5, 8-a, 8-b, 10) show close agreement.

\section{SUM MARY}

The effect of the ingestion of moderate amounts of potassium and sodium on the mineral and water balances of two normal subjects and two patients, with, respectively, nephrosis and advanced hemorrhagic Bright's disease, has been studied.

The administration of from 5 to 10 grams of potassium chloride per day did not increase significantly the excretion of sodium or edema fluid.

The correlations between base retentions and weight changes in a patient with degenerative Bright's disease were such as to indicate retentions or losses of extracellular fluid of normal base concentrations.

Similar data in a normal patient during the onset of an acute upper respiratory infection showed an excessive retention of sodium over retention of water.

The corresponding data in a patient with terminal hemorrhagic nephritis did not indicate a simple retention or loss of extracellular fluid, and suggested the occurrence of changes in the base concentrations of the body fluids.

\section{BIBLIOGRAPHY}

1. Bunge, G., Ueber die Bedeutung des Kochsalzes und das Verhalten der Kalisalze im menschlichen Organismus. Ztschr. f. Biol., 1873, 9, 104.

2. Pugliese, A., Action due chlorure de sodium et du chlorure de potassium sur l'échange matériel. Arch. ital. de biol., 1896, 25, 17.

Action des chlorures de sodium et de potassium sur le cours de l'inanition. Arch. ital. de biol., 1896, 26, 345.

3. Hart, E. B., McCollum, E. V., Steenbock, H., and Humphrey, B. C., Physiological effect on growth and reproduction of rations balanced from restricted sources. Wisconsin Agric. Exp. Stat. Res. Bull. 1911, No. 17.

4. Meyer, L. F., and Cohn, S., Klinische Beobachtungen und Stoff wichsilversuche über die Wirkung verschiedener Salze beim Säugling. Ztschr. f. Kinderh., 1911, 2, 360.

5. Gerard, P. J., Teneur en potassium et en sodium des différents organes d'un chien. Compt. rend. Acad. d. sc., 1912, 154, 839.

6. Gerard, P. J., Influence de l'alimentation sur la teneur en potassium et en sodium d'un chien. Compt. rend. Acad. d. sc., 1912, 154, 1305.
7. Gerard, P. J., Contribution à l'étude du potassium et du sodium chez les animaux. Ann. Inst. Pasteur, 1912, 26, 986.

8. Wiley, F. H., Wiley, L. L., and Waller, D. S., The effect of the ingestion of sodium, potassium, and ammonium chlorides and sodium bicarbonate on the metabolism of inorganic salts and water. J. Biol. Chem., 1933, 101, 73.

9. Miller, H. G., Potassium in animal nutrition. I. Influence of potassium on urinary sodium and chlorine excretion. J. Biol. Chem., 1923, 55, 45.

II. Potassium in its relation to the growth of young rats. Ibid., 1923, 55, 61.

III. Influence of potassium on total excretion of sodium, chlorine, calcium, and phosphorus. Ibid., 1926, 67, 71.

IV. Potassium requirements for normal growth and maintenance. Ibid., 1926, 70, 587.

$V$. Influence of potassium on urinary and fecal excretion of sodium, chlorine, calcium, and phosphorus. Ibid., 1926, 70, 593.

10. Loeb, R. F., Atchley, D. W., Dickinson, W. R., Jr., Benedict, E. M., and Driscoll, M. E., On the mechanism of nephrotic edema. J. Clin. Invest., 1932, 11, 621.

11. Richards, M. B., Godden, W., and Husband, A. D., The influence of variations in the sodium-potassium ratio on the nitrogen and mineral metabolism of the growing pig. II. Biochem. J., 1927, 21, 971.

12. Bassett, S. H., Elden, C. A., and McCann, W. S., Mineral exchanges of man. II. Effects of excess potassium and of calcium on two normal men and on an oedematous nephritic. J. Nutrition, 1932, 5, 1.

13. Blum, L., Uber die Rolle von Salzen bei Entstehung von Oedemen. Verhand. Deut. Kongr. f. inn. Med., Wiesbaden, 1909.

14. Blum, L., Alkaline salts in the pathogenesis of edema. Presse méd., 1920, 28, 685.

15. Schloss, E., Die Bedeutung der Mineralsalze in der Pathogenese und Therapie der Oedeme. Deutsche. med. Wchnschr., 1910, 36, 1027.

16. Veil, W. H., Uber die Bedeutung intermediarer Veränderungen im chlorstoff wechsel beim Normalen und beim Nierenkranken. Biochem. Ztschr., 1918, 91, 267.

17. Labbe and Voille., Metabolisme d l'eau. Masson et Cie., Paris, 1927.

18. Kempmann, W., and Menschel, H., Die Bedeutung der Kationen Natrium, Kalium, Calcium für Entstehung und Behandlung des nephritischen Odems. Ztschr. f. d. ges. exper. Med., 1925, 46, 111.

19. Gamble, J. L., Ross, G. S., and Tisdall, F. F., The metabolism of fixed base during fasting. J. Biol. Chem., 1923, 57, 633.

20. Peters, J. P., and Van Slyke, D. D., Quantitative Clinical Chemistry. I. Interpretations. Williams and Wilkins Co., Baltimore, 1931, p. 182.

21. Blumgart, H. L., Gilligan, D. R., Levy, R. C., Brown, 
M. G., and Volk, M. C., Action - of diuretics. I. Action of diuretics in normal persons. Arch. Int. Med., 1934, 54, 40.

22. Lavietes, P. H., D'Esopo, L. M., and Harrison, H. E., The water and base balance of the body. J. Clin. Invest., 1935, 14, 251.

23. Peters, J. P., and Van Slyke, D. D., Quantitative Clinical Chemistry. II. Methods. Williams and Wilkins Co., Baltimore, 1932, p. 78.

24. Van Slyke, D. D., Stillman, E., Mфller, E., Ehrich, E., McIntosh, J. F., Leiter, L., MacKay, E. M., Hannon, R. R., Moore, N. S., and Johnston, C., Observations on the courses of different types of Bright's disease, and on the resultant changes in renal anatomy. Medicine, 1930, 9, 257.

25. Leiter, L., Influence of previous salt regime on excretions of chlorine, sodium, and potassium during the chloride concentration test of de Wesselow. J. Clin. Invest., 1926, 3, 253.

26. Butler, A. M., Acidosis or alkalosis in infants and children with gastro-intestinal disturbances, chronic nephritis and diabetes mellitus. M. Clin. North America, Jan. 1935.

27. Butler, A. M., and MacKay, E. M., The influence of the sodium and potassium content of the diet upon the sodium concentration of human centrifuged red blood cells. J. Biol. Chem., 1934, 106, 107.

28. Sunderman, F. W., Studies of serum electrolytes. IV. The chloride and nitrogen balances, and weight changes in pneumonia. J. Clin. Invest., 1929, 7, 313.

29. Austin, J. H., and Sunderman, F. W., Studies of serum electrolytes. V. Urinary electrolyte excretion in pneumonia. J. Clin. Invest., 1929, 7, 333.

30. Blum, L., and Grabar, P., Composition minerale des organes d'un sujet normal. Compt. rend. Soc. de biol., 1929, 101, 715.

31. Davidson, W. C., and Salinger, R., Tubular nephritis (nephrosis) in children and its relationship to other forms of nephritis. Bull. Johns Hopkins Hosp., 1927, 41, 329. 